\title{
Obituary
}

\section{Dave Laing}

The last time I met Dave Laing he explained to me the peculiarities of being a journalist on the obituary beat, as he had been for many years for the Guardian. The basic requirement of the job was obvious enough - a wide-ranging knowledge of and curiosity about everyone in one's specialist field (popular music, widely defined, in his case) - but I had never thought before about an obituary's conventional narrative shape: an introduction, summarising the subject's public life and achievements; a middle section, providing basic personal and domestic details - date of birth and place of upbringing, parents' occupation, schooling and further education, initial career steps; and a finale, an account of the subject's later life, influence and historical status. This was the section of the obituary in which the journalist was most likely to mention their own admiration of the person they were writing about.

Dave also observed wryly that obituary writing could be an unexpectedly competitive pursuit. The Guardian's various music obituarists had had, for some time, an informal agreement about the distribution of subjects to writers - according to different musical worlds, levels of fame and so forth. However, a new contributor had appeared, willing and able to write about anyone, particularly anyone who for whatever reason wasn't already covered in the obituary bank. Dave had found himself keeping an ear out for the earliest possible news of someone's death and having to race to be the first person to reach the obituary page editor.

It did cross my mind to ask Dave if he'd already written my obituary but I didn't want to reveal my vanity, and I would have been appalled to know that I might so soon be writing his. Yet I remember this conversation fondly anyway because it was so typical of many conversations we had. I never talked to him without learning something new and marvelling at his range of knowledge, his ability to illuminate a topic, his practical understanding of both music and writing, and his modesty and wit.

I was expecting to talk to Dave again after he'd read the proof copy of the second volume of our live music history, which, alas, I never got to send him. Ever since I first met him, around 1971, Dave has been the reader in my head, the person most likely to spot mistakes and omissions and to challenge unnecessarily fancy theorising. He did read (and point out the mistakes) in volume 1, and our interesting conversation then was about the people in popular music history who are not widely known or feted but who, in fact, best embody cultural change. The example we discussed was the writer, manager, producer, studio owner and hit maker Denis Preston (misspelt as Dennis in the book's index, as Dave was quick to point out), whose name appears on a great variety of jazz, pop, calypso, highlife and novelty records in the 1950s and early 1960s. I mention this here because Dave Laing is the person who best embodies the history of popular music studies in Britain. His biography is the biography of the field. 
This can be illustrated in a number of ways. Begin with the life. Dave was born in January 1947, part of the post-war population boom that was the demographic underpinning of the 1960s rise of a teen- and then student-aimed music business. He was one of many clever 1960s grammar/public schoolboys who were committed rock ' $n$ ' roll fans before they got to university. Dave went to Cambridge and although he left after a couple of years (rusticated for cannabis use he once told me) he had developed enough confidence (and read enough German political sociology and French literary theory) to write and get published (by a Roman Catholic publisher, which greatly impressed me at the time) what was, it was to turn out, the first work of British popular music studies. The Sound of Our Time was published in 1969, the year before The Sound of the City by Charlie Gillett, another grammar school boy and Cambridge student, and Dave and Charlie were to become central figures in the early history of the British rock press, first on Cream and then as founding editors of Let It Rock.

The Sound of our Time was, rather remarkably, a gap year project. After its completion Dave resumed his university education at the University of Sussex, at that time a rather trendy university that was pioneering cross-disciplinary education and critical cultural studies. Dave became part of a group of writers, most importantly Phil Hardy, an American Studies student who had helped launch the Brighton Film Review and was to collaborate with Dave on a number of publishing projects.

Rock writing in Britain emerged in the early 1970s from a variety of sources, in all of which Dave seemed to have a significant role. He was music editor for a number of left-wing/underground papers as well as a writer in the music press (for Sounds as well as Cream and Let It Rock); he was involved in a range of new music book publishing projects. His contribution to Phil Hardy's Rockbooks series, Buddy Holly (1971), was the first example of what was to become an essential element of popular music studies, the analytical artist monograph, while The Electric Muse. The Story of Folk into Rock (1975), which Dave edited for a new Methuen music book series, was accompanied by four-album anthology from the Island and Transatlantic catalogues and remains a rich source for folk music historians.

In the later 1970s, as indie rock magazines folded and the underground press withered, Dave's writing career developed in new directions. He and Hardy were at the forefront of a new market for rock reference books, for the pop and rock encyclopaedias that were soon being published across Europe. Their three-volume Encyclopaedia of Rock (1976) was not only undogmatically comprehensive but also a valuable earning opportunity for freelance music writers (to whom Dave had previously given space in the various magazines for which he worked). These volumes would eventually be consolidated into the mainstream Faber Companion to $20^{\text {th }}$-Century Popular Music (1990), but Dave had already been involved (alongside Charlie Gillett and John Pidgeon, his successor as editor of Let it Rock) with Tim Blackmore's 26-part Radio 1 series, The Story of Pop (and with the loosely connected part-work magazine and series of anthology albums). This oral history prefigured Dave's later important music industry interviews for the British Library's Sound Archive.

Unlike most of Britain's early rock writers Laing and Hardy had also always been interested in the business of music - one of Dave's earliest post-Let It Rock projects was a short-lived magazine aimed at retailers, to which I contributed, although I can't recall its title. Dave now became a pioneering music industry journalist. In the 
1980s he was press officer for IFPI and deputy editor of Music Week (with the brief of covering music publishing) before becoming launch editor of its associated magazine, MBI (Music Business International). In 1992 he and Phil Hardy began issuing Music \& Copyright, an industry newsletter published by the Financial Times for record company executives, media analysts and policymakers. This was launched, as Dave explained in his Hardy obituary, 'after Phil and I had managed to persuade sceptical FT managers that the music industry was more than just a bunch of overpaid exhibitionists and drug takers'.

This was the decade in which Dave developed his empirical research skills, his mastery of music business statistics and his range of music industry contacts, particularly in Europe. He was, not surprisingly, the key contributor as well as one of the editors of Continuum's Encyclopaedia of the Popular Music of the World, which began appearing in 2003. Such skills were the basis of his career as an 'independent scholar', as an in-demand researcher for a variety of music organisations, policymakers and funding agencies. Music in Between (1986), for example, co-authored by the jazz musician Tony Haynes, was 'a comprehensive study of the working lives and career development of contemporary creative musicians', funded by the Gulbenkian Foundation; Thirty Years of the Cambridge Folk Festival (1994), co-authored by Richard Newman, was written for the festival; Nice Work If You Can Get it (2000), co-authored by Norton York, was 'a study of musicians' employment between 1978 and 1988, commissioned by the Musicians' Union.

Such studies were the model for popular music academics who at the turn of the century were increasingly involved in policy research and methodological issues in the 'measurement' of the music economy. Dave was obviously now a part of this academic world too, not just as a long-standing member of the editorial board of Popular Music but also, for example, as a research fellow at the University of Westminster, a visiting fellow of the Liverpool Institute of Popular Music and a member of the CREATE research team at the University of East Anglia.

If Dave Laing's life can be said to embody the history of popular music studies, it did so because of the range of his interests and abilities. This is, perhaps, most obvious in his best known book, his punk study One-Chord Wonders (1985), a remarkable work not just for its coolly engaged tone - Dave neither patronises nor romanticises the music - but also for the way it combines so many analytic approaches.

It is in part a work of political economy. Dave was both familiar with Marxist cultural analysis (he had published his elegant overview, Marxist Theory of Art in 1978) and had the rare gift (for the time) of standing outside sectarian dispute while always enjoying a political argument, whether at the early 1970s meetings of the Rock Writers' Collective or in his mid-1970s involvement in Music for Socialism. It is in part a work of textual analysis, of continental literary theory and semiotics. Dave had a literature and sociology degree, and his early rock criticism tended to focus on singer/songwriters and their words. He remained suspicious of what he regarded as under-theorised social science. And it is in part a history. As he was to show in his resource notes for the journal Popular Music History Dave was, among all his other skills, adept at finding and using sources for musical historical research of all sorts, most recently in his documentation of British rock magazines and rock writers.

I knew all this but when we started our Live Music research I was, nevertheless, still astounded by the range of Dave's relevant publications (which I've only touched on here). He wrote about popular music in the 1890s, the geographical distribution of 
beat group gigs in North West England in the 1960s, on Woodstock, Elton John and rock and sexuality in the 1970s, on copyright and the collecting agencies in the 1980s, on the Licensing Act of 2003, and on world record sales throughout this period. It became a private challenge for me to find an important topic in popular music studies on which Dave hadn't written. I haven't yet done so.

Looking back it is equally startling to realise how many roles Dave played in his career: author, critic, researcher, statistician, publicist, archivist, oral historian, and so forth, although I think his greatest role was as an editor and friend (friendship is an underrated scholarly quality). As the many tributes that have been paid to Dave on social media since his death make clear, what people (younger scholars in particular) most appreciated about him was his friendliness, his encouragement, his openness, his advice and support.

When I think back to the times we met I remember too the many and varied people he knew and was happy to introduce me to. Phil Hardy and Charlie Gillett, of course but also the blues scholar, Mike Leadbitter and Bob Dylan's first biographer, Robert Shelton, the jazz critic Brian Case and the jazz photographer and writer, Val Wilmer (with whom he worked on an unpublished photo project in mining towns), the pioneering British music journalist Penny Valentine and the distinguished Finnish historian of the recording industry, Pekka Gronow.

And I remember the places we met. An obscure drinking club in Soho one afternoon (in which Clive James quietly slept at the end of the bar); John Pidgeon's living room in Clapham where he, Dave and I passed instant judgement on all the albums Let It Rock had received but not put out for review - my job was to write up their snap judgements for the monthly column, 'Shortcuts by the Demon Barber'; with Pete Frame on a small plane to Memphis taking us to the one and only meting of the International Rock Writers Convention - as we ran into turbulence Dave tried to remember the flight number of the plane in the Everly Brothers' 'Ebony Eyes' (1203); and at many many meetings of the editorial board of Popular Music or, rather, at the after-meetings in the pub. In all the pictures in my head, Dave is holding a beer glass but never, in my memory, did he ever get muddled or aggressive. Perhaps he cast an even more quizzical eye than usual over our pronouncements, but he always remained courteous, open-minded, helpful and above all enthusiastic. He was the most unselfish scholar I've ever known and the first point of call for information about books, people, sources, articles, ideas or contacts. He will be missed to an extent that I don't think we yet realise.

SIMON FRITH 